\title{
ギャップモードラマン分光の種々の基板への適用†
}

\author{
石倉真保・鈴木悠宜・二又政之 \\ 埼玉大学 大学院理工学研究科 齿338-8570 埼玉県さいたま市桜区下大久保 255 \\ （2015 年 2 月 12 日受付；2015 年 4 月 22 日掲載決定）
}

\section{Relevance of Gap Mode Raman Spectroscopy to Various Substrates}

Maho Ishikura, Hiroki Suzuki and Masayuki Futamata

Saitama University, 255 Shimookubo, Sakura-ku, Saitama 338-8570

(Received February 12, 2015 ; Accepted April 22, 2015)

\begin{abstract}
In order to clarify the relevance of gap mode Raman spectroscopy in metal nanoparticles/gap/metal substrates, we investigated the effect of dielectric constants of substrates, and the size of gold nanoparticles (AuNPs). First, we obtained pronounced enhancement of $10^{5}-10^{8}$ in Raman scattering of thiol molecules on various metal substrates with large damping, and even on silicon substrates. Also, significantly larger enhancement was obtained for larger AuNPs, fopr example by a factor of $10^{3}$ for larger particles with a radius (r) of $50 \mathrm{~nm}$ compared with those with $\mathrm{r}=15 \mathrm{~nm}$. These experimental observations can be explained by a coupling of dipole in AuNPs formed at localized surface plasmon resonance, and image dipole induced in the substrates. The observed properties in gap mode Raman spectroscopy are consistent with those anticipated by theoretical calculations using finite difference time domain (FDTD) method.
\end{abstract}

KEYWORDS : surface enhanced Raman scattering, localized surface plasmon, gap mode, external geometry, FDTD calculations

\section{1.は じめに}

種々の界面に in situ で適用できるラマン分光法は，分 子内の結合に由来する振動スペクトルから分子の構造・ 配向性・周囲の化学種との相互作用等について詳しい情 報を与える。ただし, 従来のラマン分光法では, 感度が 足りず，単分子層検出も容易ではない。約 40 年前に, 粗さを持った金属表面吸着種のラマン散乱信号強度が, $10^{4} \sim 10^{6}$ 倍増強されるという表面増強ラマン散乱（surface enhanced Raman scattering, SERS ${ }^{1 \sim 3)}$ ) が発見され, 大きな注目を集めた。最近, 精密な化学還元・結晶成長 制御法の開発や電子ビームリソグラフィ法などの利用 で，単一分子感度レベルの大きな SERS 増強度を示すナ ノ構造形成が可能となり，再び注目されている。

SERS の增強メカニズムとしては, 金属表面と吸着種 間の電荷移動相互作用による化学的増強と, 金属ナノ構

\footnotetext{
†第 34 回表面科学学術講演会（2014 年 11 月 6 日〜 8 日） にて発表

E-mail : futamata@chem.saitama-u.ac.jp
}

造の局在表面プラズモン（localized surface plasmon, LSP）の光励起による電磁気学的増強が知られている。 前者は, 吸着分子と金属の組み合わせや振動モードの対 称性などに依存する選択的な増強 $\left(10^{2} \sim 10^{3}\right.$ 倍) であ る ${ }^{3)}$ 。一方, LSPによる増強電場は, 吸着種の種類によ らないため沉用性が高い。ただし, 孤立金属ナノ構造の LSP による電場増強は, 10〜 $10^{2}$ 倍であり, SERS 増強 度として約 $10^{4}$ にとどまる ${ }^{1,2)}$ 。金属ナノ構造体で, $10^{4}$ $\sim 10^{6}$ 倍の電場増強と単一分子ラマン感度 $\left(\sim 10^{10}\right.$ のラ マン増強度）を得るために, 近接する金属ナノ粒子の LSP カップリングが有効である ${ }^{1 \sim 2)}$ 。たとえば，分析対 象分子との相互作用を制御することで近接金属ナノ粒子 を形成し，ナノギャップに存在する化学種を高感度でラ マン分光測定する flocculation-SERS 法の開発が進められ ている ${ }^{4 \sim 9)}$ 。この近接する金属ナノ粒子のうち, 一方を 金属基板に替えたギャップモード配置でも，金属粒子間 と同様にナノギャップで大きな増強電場およびラマン増 強が得られることが知られている ${ }^{10)}$ 。さらに, ギャップ モードにおける金属ナノ粒子を, AFMのカンチレバー 
や先鋭化した光ファイバ先端に固定し, 試料表面を 3 次 元走查することで, トポグラフィとともに近接場ラマン イメージングの実現が可能である（チップ増強ラマン, tip-enhanced Raman scattering, TERS) ${ }^{11}$ 。このとき, 金属 基板と金属ナノ粒子間のギャップモードを励起すること で, 単一分子感度を実現できると同時に, 増強電場の広 がり（粒子サイズの 1/4 1/5）で決まる数 $\mathrm{nm}$ の空間 分解能が期待されている。さらに, 全反射配置で伝搬性 表面プラズモン (propagating surface plasmon, PSP) とギ ヤップモードを複合して, 外部反射配置よりも大きなラ マン増強度を得ることが可能である ${ }^{12 \sim 14) 。 ~}$

ギャップモードは，金属ナノ粒子側から入射光を照射 する外部反射配置で利用される場合が多い。このとき, ナノギャップの増強電場の形成は以下のメカニズムによ り説明できる。減衰の小さな金ナノ粒子, 銀ナノ粒子な どの系では，共鳴波長のレーザー光を用いることで，金 属ナノ粒子の LSP が励起される。この LSP 励起により 金属ナノ粒子内部に形成される振動双極子 $\boldsymbol{p}$ は, 金属基 板内に鏡像双極子 $\boldsymbol{p}$ 'を誘起する。これらの双極子-双極 子の相互作用により, ナノギャップに大きな増強電磁場 が形成される。このとき, 鏡像双極子 $p$ の大きさは次 式で与えられる (Fig. 1) ${ }^{15)}$ 。

$$
\left|\boldsymbol{p}^{\prime}\right|=|\boldsymbol{p}| \times\left(\varepsilon_{1}-\varepsilon_{2}\right) /\left(\varepsilon_{1}+\varepsilon_{2}\right)
$$

ここで, $\varepsilon_{1}, \varepsilon_{2}$ は，それぞれ金属基板掞よび媒質の誘電 率である。この式から明らかなように，媒質に比べ大き な誘電率を持つ金属あるいは非金属であれば，減衰があ る程度大きくても金属ナノ粒子の双極子に匹敵する大き さの鏡像双極子が形成されることから, 従来の SERS 研 究では利用できなかった $\mathrm{Pt}, \mathrm{Rh}$ などの触媒を含め害用 性の高い種々の金属基板への適用が可能となる ${ }^{16 \sim 18)}$ 。 実用的な観点からは，金属基板上の吸着分子との van der Waals 力や静電的相互作用などを制御して, 効率的

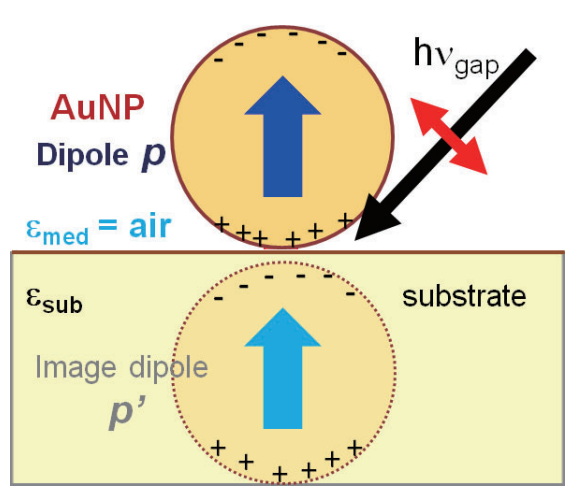

Fig. 1. (color online). Gap mode under an external geometry for AuNP/gap/metal substrate (see details in main text).
に金属ナノ粒子を固定する必要がある ${ }^{19)}$ 。 本研究では, 外部反射配置のギャップモードの有用性 を実証するために，金ナノ粒子/ギャップ/金属基板の系 について, ナノギャップの電場増強度の基板の材質や金 ナノ粒子サイズに対する依存性について検討した。この ために, 時間領域差分法（FDTD 法）を用いてナノギャ ップ近傍の電場の局所分布計算を行った。並行して, チ オール分子が自己組織化単分子膜を形成する種々の金属 表面に ${ }^{20)}$, van der Waals 相互作用により効率的に金ナノ 粒子を固定できるチオフェノール単分子膜 ${ }^{19)}$ 種々の金 属基板に形成し, 実験的な検討を行い, 計算結果と比較 した。

\section{2. 実 験 方 法}

本研究で用いた AuNP は, 塩化金酸 $\left(\mathrm{HAuCl}_{4}\right)$ 水溶 液を沸騰させながらクエン酸で還元して形成したもので ある ${ }^{6,7,21)}$ 。原料組成のほか反応温度や熟成時間等によ り, 粒子形状やサイズを制御することが可能である。こ こでは，5分間程度の加熱により AuNPを形成した。 AuNP は, 半径約 $15 \mathrm{~nm}$ の球状粒子, 濃度は〜 $10^{11}$ 個/ $\mathrm{mL})$ で, $~ 25 \mathrm{~nm}$ に extinction peak を与えた。このピ ーク波長は, 溶液中で孤立した AuNP の LSP 共鳴によ るものである。一般に化学還元で形成した金属ナノ粒子 表面には, クエン酸や分解物であるアモルファスカーボ ンなどの表面残留物が付着している。クエン酸アニオン による静電反発のため, 水溶液に分散した金ナノ粒子 は, 孤立状態で数か月間安定に存在する。

種々の金属基板（純度 $99.99 \%, \mathrm{Cu}, \mathrm{Al}, \mathrm{Sn}, \mathrm{Pb}$, $\mathrm{Zn}, \mathrm{Ti}, \mathrm{V}, \mathrm{Ni}, \mathrm{Pd}, \mathrm{Pt}$ ) をニラコ(株)から購入し, 必 要に応じて酸処理して表面酸化物を除去したのち, チオ フェノール (Thiophenol, TP) 分子の SAM 膜をエタノー ル溶液への基板の浸漬により形成した。余分なチオール は, 純溶媒でリンスし除いた。その後, AuNPの分散液 を基板上に滴下し, 十分な時間（２２時間）静置後，固 定できていないAuNPをリンスし除いた。AuNP 固定前 後の TP のラマンスペクトル測定を, He-Ne レーザー $\left(632.8 \mathrm{~nm}, \sim 7 \mathrm{~mW}, \mathrm{p}\right.$-偏光, 入射角 $\left.\sim 60^{\circ}\right)$ で, 顕微ラ マン分光系を用いて行った。バルク状態の TP 分子のス ペクトルとの比較, 走查型電子顕微鏡観察による AuNP 被覆率の測定, FDTD 法による SERS 活性領域の広がり などを用いて, ナノギャップにおける吸着種のラマン信 号の增強度を見積もった。

\section{3. 結 果 と考察}

\section{1 FDTD 計算 ${ }^{14)}$}

金ナノ粒子（半径 $15 \mathrm{~nm}$ )/ギャップ（1 nm)/金属基板 


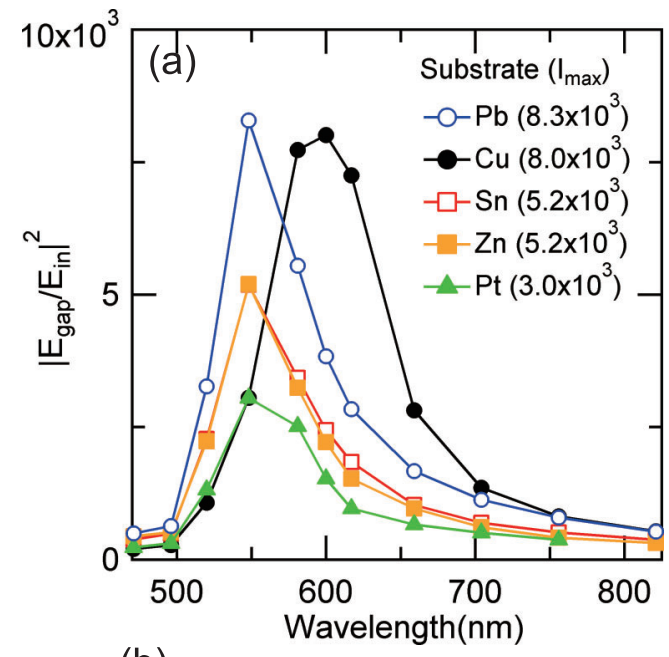

(b)

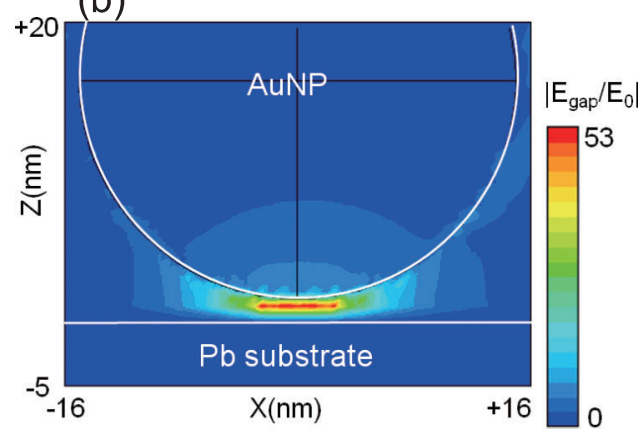

Fig. 2. (color online). Gap mode resonance and enhanced electric field intensity for AuNP $(r=15 \mathrm{~nm}) / \mathrm{gap}(1 \mathrm{~nm}) /$ metal (M) substrates, here $\mathrm{M}=\mathrm{Pb}, \mathrm{Cu}, \mathrm{Sn}, \mathrm{Zn}$ and $\mathrm{Pt}$, calculated with an FDTD method: (a) at various excitation wavelengths, (b) spatial distribution at a nanogap for $\mathrm{Pb}$ substrate. Only nanogap region was shown, while much wider region of $460 \mathrm{~nm}(\mathrm{X}) \times 460 \mathrm{~nm}(\mathrm{Y}) \times 260 \mathrm{~nm}(\mathrm{Z})$ was used for calculation.

系におけるナノギャップの電場の大きさ $\left(\left|\mathrm{E}_{\mathrm{gap}} / \mathrm{E}_{\mathrm{o}}\right|^{2}\right.$, こ こで, $\mathrm{E}_{\mathrm{gap}}$ : ナノギャップでの振幅電場, $\mathrm{E}_{0}$ : 入射光の 振幅電場）は，減衰の大きな遷移金属でも種類に依らず $10^{3} \sim 10^{4}$ の大きな值を示した (Fig. 2, Table 1)。これ は, 金基板や銀基板での $10^{4} \sim 10^{5}$ の值に比べやや弱い ものの十分に大きな值である。このとき，滅衰の大きな 金属基板上では, メカニズムから予想されるように，ギ ヤップモード共鳴は, 金ナノ粒子の LSP 共鳴（共鳴波 長=半径 $15 \mathrm{~nm}$ のとき $520 ５ 30 \mathrm{~nm}$ ）に支配されてい る。

金ナノ粒子/ギャップ/アルミニウム基板系で，ギャッ プサイズを変えたときの電場強度の励起波長依存性を詳 しく計算したところ, Fig. 3 に示すように, ギャップサ イズの増大とともに, 孤立 Au 粒子の LSP 共鳴に近づく ことが確かめられた。また, 電場の増強度 $\left(\left|\mathrm{E}_{\mathrm{gap}} / \mathrm{E}_{0}\right|^{2}\right)$ の值は, 特にギャップサイズ $2 \mathrm{~nm}$ 以下で, $10^{4}$ 倍以上
Table 1. Enhancement factor for SERS signal intensity of TP under a gap mode resonance, AuNP(r nm)/gap/TP/metal substrates.

\begin{tabular}{lllll}
\hline $\begin{array}{l}\mathrm{r}_{\text {AuNP }} \\
(\mathrm{nm})\end{array}$ & $\begin{array}{l}\text { Calc. }^{*} \\
15\end{array}$ & 50 & $\begin{array}{l}\text { Obsd. } \\
{ }^{* *}\end{array}$ \\
\hline $\mathrm{Ag}$ & $13\left(\times 10^{6}\right)$ & $102\left(\times 10^{8}\right)$ & $16\left(\times 10^{5}\right)$ & $13\left(\times 10^{7}\right)$ \\
$\mathrm{Cu}$ & 53 & 118 & 3.3 & 3.4 \\
$\mathrm{~Pb}$ & 8.1 & 62 & 1.5 & 1.3 \\
$\mathrm{Zn}$ & 2.3 & 13 & 13 & 1.3 \\
$\mathrm{Ni}$ & 2.8 & 9.0 & 0.96 & 1.4 \\
$\mathrm{Pt}$ & 2.3 & 8.1 & 0.98 & 1.1 \\
$\mathrm{Si}$ & 5.3 & 1.8 & & 0.1 \\
\hline
\end{tabular}

${ }^{*}\left|\mathrm{Egap}_{\mathrm{gap}} / \mathrm{E}_{0}\right|^{4}$,

** Ratio of ISERS/molecule at nanogap to IRaman/molecules at bulk state.

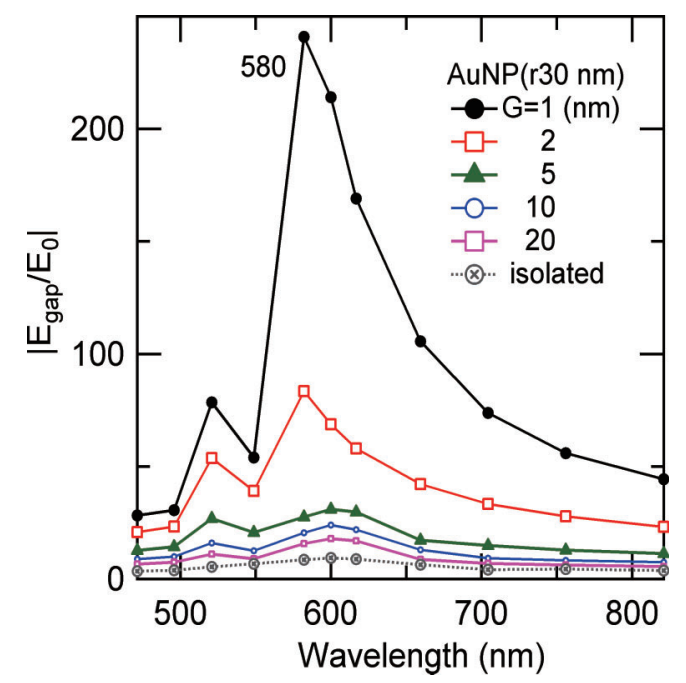

Fig. 3. (color online). Local electric field amplitude $\left(\left|E_{\text {gap }} / E_{\text {in }}\right|\right)$ at a nanogap for AuNP $(r=30 \mathrm{~nm}) / \operatorname{gap}(\mathrm{G}) / \mathrm{Al}$ substrate as a function of gap size.

に急激に増大することがわかった。

金ナノ粒子の半径を $15 \mathrm{~nm}$ から $50 \mathrm{~nm}, 100 \mathrm{~nm}$ へと 大きくすると, ナノギャップでの電場増強度はしだいに 増大した (Fig. 4 a)。これは, 金ナノ粒子サイズの増大 とともに粒子内部の電子数が増大し, LSP 励起時に, 上 り大きな双極子が形成されるためと解釈できる。興味深 いことに, 金ナノ粒子サイズの増大に伴い，共鳴波長の 幅が広がり, 半径 $50 \mathrm{~nm}$ では 600 $800 \mathrm{~nm}$ 付近まで, 半径 $100 \mathrm{~nm}$ では $800 \mathrm{~nm}$ を超えて近赤外領域まで, 共 鳴波長が広がることが判明した。この結果は, ギャップ モードの応用面から，十分大きな金ナノ粒子を用いる限 り，レーザー光波長を厳密に選択する必要がないこと， および生体系等で近赤外領域の励起光を利用する場合な どに有用と考えられる。さらに, 基板の誘電率が比較的 


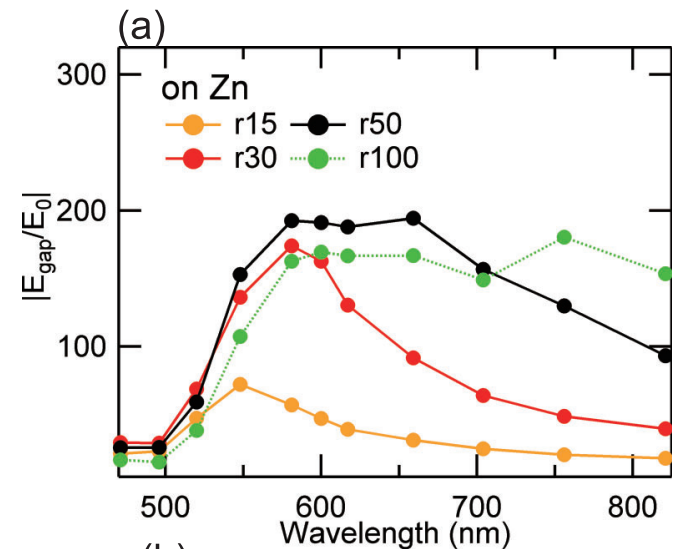

(b)

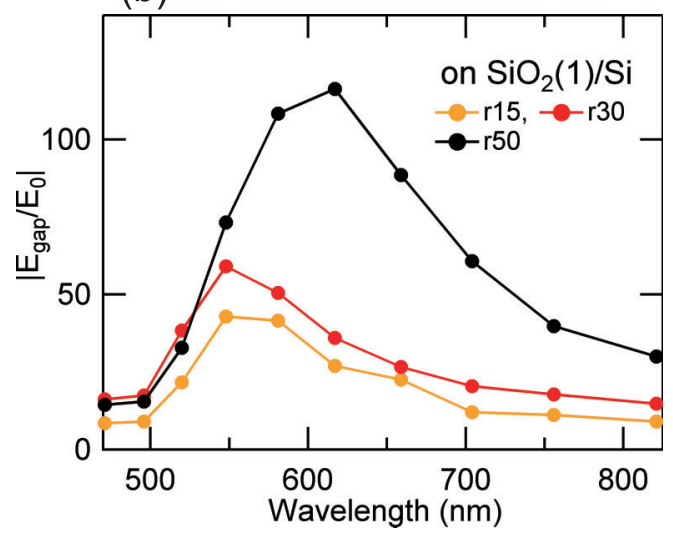

Fig. 4. (color online). Local electric field amplitude $\left(\left|E_{\text {gap }} / E_{\text {in }}\right|\right)$ at a nanogap for AuNP (r nm)/gap (1 nm)/Zn (a) and $\mathrm{Si}$ (b) substrate for different AuNP sizes. Similar results obtained for various metals.

大きなシリコン基板 $(\varepsilon=+15.4+\mathrm{i} 0.2)$ を用いたとき, 減衰の大きな遷移金属基板に近い $1.4 \times 10^{4}$ 倍の増強電 場が形成された (Fig. 4 b)。この值は, ガラス基板 $(\varepsilon=2.1)$ に比べて 100 倍程度大きく, 双極子-双極子モ デルでの予測とよく一致した。

このような滅衰の小さな金属ナノ粒子/ギャップ/隇衰 の大きな金属基板系 $(\mathrm{AgNP} / \mathrm{gap} / \mathrm{Pt}$ 基板）のギャップ モード配置（®）の代わりに，隇衰の大きな金属ナノ粒 子/ギャップ/減衰の小さな金属基基板 $(\mathrm{PtNP} / \mathrm{gap} / \mathrm{Ag}$ plate）の系（B) で, FDTD 計算を行ったところ, (A) Bとで，ほほ同じ程度の大きさの増強電場が形成された (Fig. 5)。PtNP の LSP 共鳴はきわめてブロードであ $\eta^{22)}, 450 \sim 800 \mathrm{~nm}$ では增強電場は 12〜16 倍で, 大き な波長依存性を示さないことから, 金属ナノ粒子の LSP 共鳴のメカニズムとともに, PtNP 近傍に形成されるエ バネッセント波を介した銀基板表面の PSP 励起が，ナ ノギャップの電場増強に寄与するものと考えられる。

上記のように，金属ナノ粒子/ギャップ/金属基板系の ギャップモード増強メカニズムに関して, 一方の金属と

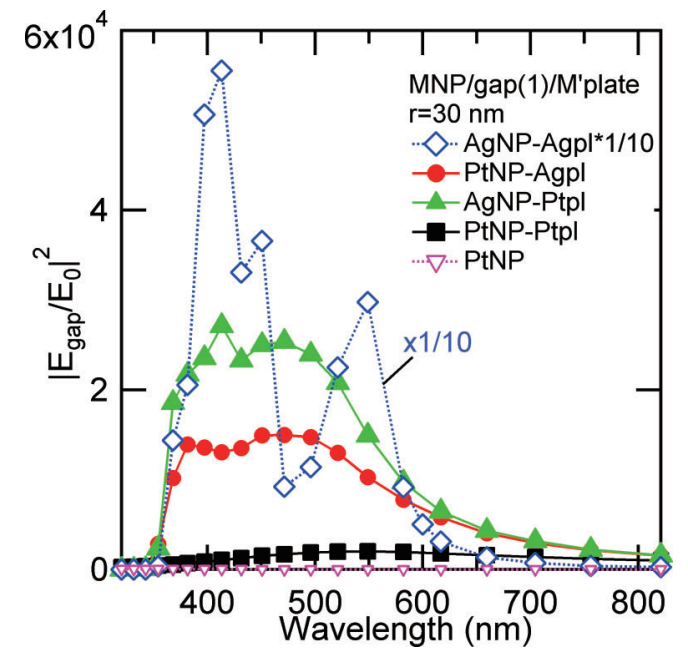

Fig. 5. (color online). Local electric field $\left(\left|\mathrm{E}_{\text {gap }} / \mathrm{E}_{\text {in }}\right|^{2}\right)$ at a nanogap for MNP $(\mathrm{r}=30 \mathrm{~nm}) / \mathrm{gap}(1 \mathrm{~nm}) /$ metal(M') substrate for different metals.

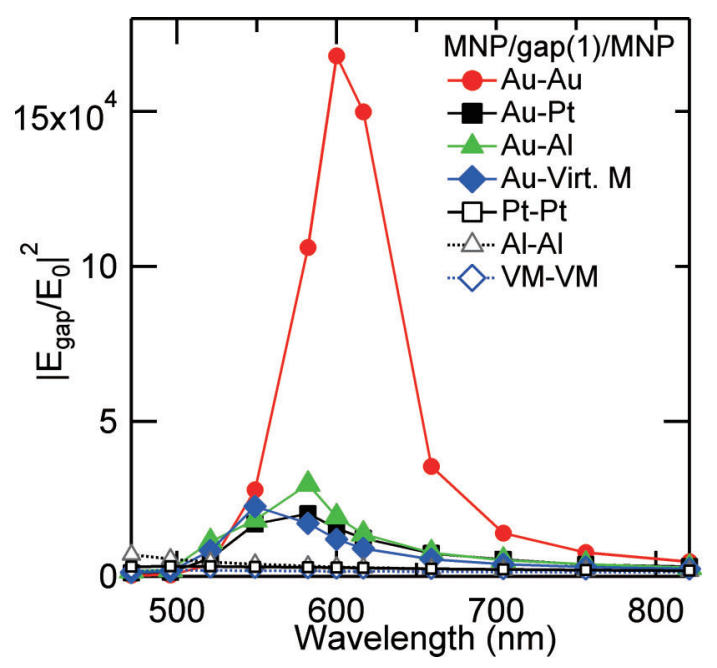

Fig. 6. (color online). Local electric field $\left(\left|\mathrm{E}_{\text {gap }} / \mathrm{E}_{\text {in }}\right|^{2}\right)$ at a nanogap for MNP ( $\mathrm{r}=30 \mathrm{~nm}) / \mathrm{gap}(1 \mathrm{~nm}) / \mathrm{M}^{\prime} N P$ for different metals. Here, $\mathrm{VM}=$ virtual metal with $\varepsilon_{\mathrm{VM}}=-1+100 \mathrm{i}$.

して減衰の小さな金属を使用する限り他方は減衰が大き な金属の場合でも, 十分大きな電場増強が得られること が判明した。この点は，近接する金属ナノ粒子に扔ける ナノギャップの増強電場を用いる flocculation-SERS 法で も利用できる可能性がある。そこで, 金ナノ粒子同士 (a. AuNP-AuNP), 金ナノ粒子と減衰の大きな金属ナノ 粒子の組み合わせ (b. AuNP-MNP), および減衰の大き な金属ナノ粒子同士（c. MNP-MNP）の系について, FDTD 計算を行ったところ，Fig. 6 に示すように，基板 上のギャップモード配置と同様に，それぞれ $10^{5}$ (a), $10^{4}(\mathrm{~b}), 10^{3}$ (c) の電場增強を与えることが判明した。 
(a)

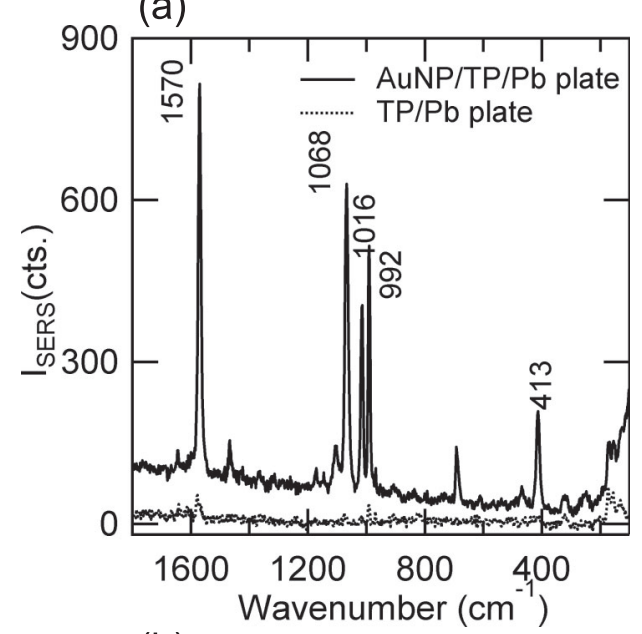

(b)

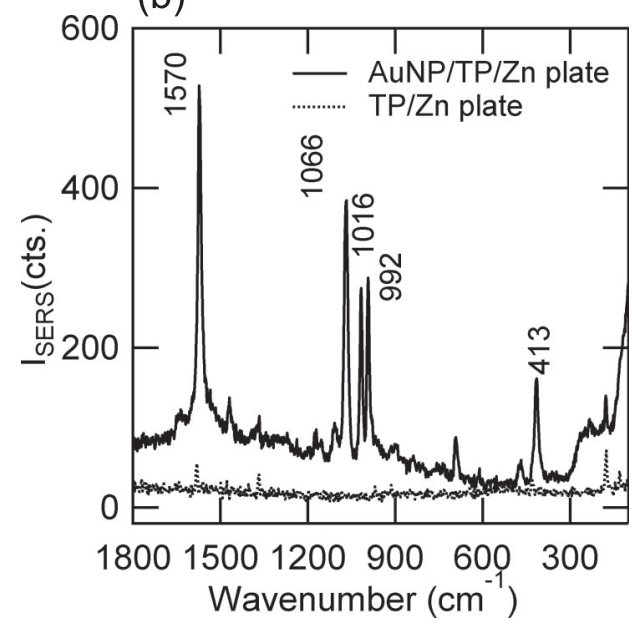

Fig. 7. Raman spectra for AuNP $(r=15 \mathrm{~nm}) /$ gap $(1 \mathrm{~nm}) /$ M'NP for different metals, here $\mathrm{M}^{\prime}=\mathrm{Pb}$ (a) and $\mathrm{Zn}(\mathrm{b}$ ).

\section{2 実験結果}

計算結果と対応する実験として, 金ナノ粒子 (半径 $15 \mathrm{~nm}$ および $50 \mathrm{~nm}$ ) を用いて, 種々の基板上に吸着さ せた TP-SAM 膜のラマンスペクトル測定を行った（Fig. 7 および Fig. 8)。どの金属基板上でも，AuNP を固定す る前は,ラマンスペクトルが観測されなかったが, AuNP の固定により大きなラマン信号が検出された。金 ナノ粒子固定性は, 金属表面状態にも依存するため見か け上スペクトル強度は異なるものの, ナノギャップにお いて，基板金属の種類に依らず，AuNPの固定により大 きなラマン増強度が得られた（半径 $15 \mathrm{~nm}$ のとき $10^{5}$ $10^{6}$ の増強度, Table 1)。このとき, SEM 測定により, 金属基板上での AuNP 被覆率を測定し, ナノギャップに 存在する TP 分子 1 個あたりのラマン信号強度をバルク 液体状態と比較し, ナノギャップでのラマン信号光の増 強度を見積もった。さらに, AuNPの粒子サイズを半径 $15 \mathrm{~nm}$ から $50 \mathrm{~nm}$ に大きくすると，10〜100 倍大きな $10^{7} \sim 10^{8}$ 倍のラマン増強度が得られた。同様に, シリコ ン基板に適用し金属基板に近い $10^{6}$ 倍のラマン信号増強 度を得ることができた（Table 1)。

ごく最近まで，これらの減衰の大きな遷移金属表面で は，SERS は有効に利用できないと考えられてきた。し かし，ここで示したように，金ナノ粒子や銀ナノ粒子を 用いる限り，幅広い金属基板でギャップモード効果によ り, 巨大なラマン増強が得られることが明らかとなっ た。

\section{4. を め}

金属ナノ粒子/ギャップ/吸着種/金属基板の系におけ るギャップモードラマン分光法の実用性を明らかにする ために，(1）種々の金属基板に適用し，106 ～108 のラマ (a)

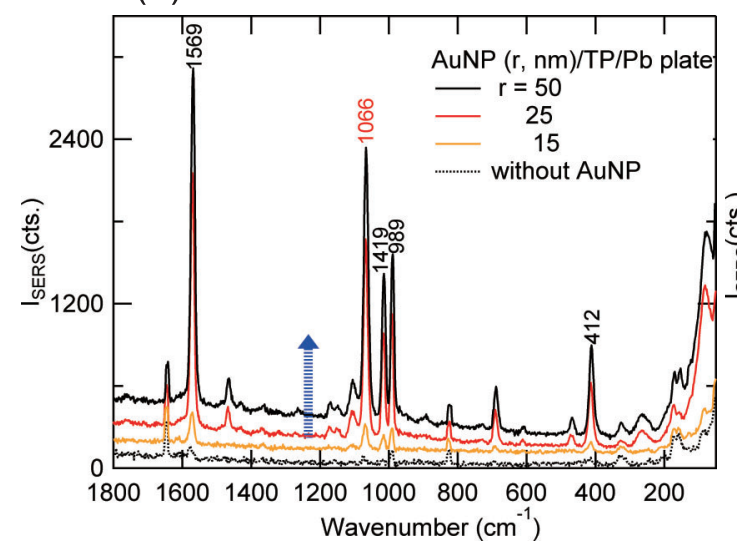

(b)

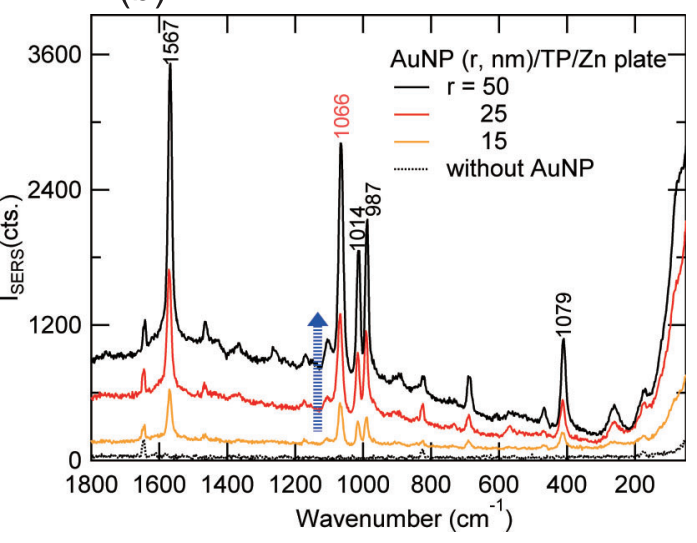

Fig. 8. (color online). Raman spectra for AuNP (r nm)/gap (1 nm)/M’NP as a function of AuNP size, here $\mathrm{M}^{\prime}=\mathrm{Pb}(\mathrm{a})$ and $\mathrm{Zn}(\mathrm{b})$. 
ン増強度が得られること，(2）金ナノ粒子のサイズと共 に，より大きなラマン散乱増強度が得られることを見い だした。（3）また, 増強メカニズムについて, ナノ粒子 の LSP の双極子と基板内に誘起された鏡像双極子の力 ップリング，およびナノ粒子のエバネッセント波による PSP 励起が寄与していることが確かめられた。ギャップ モード法は, TERS との複合等により, 局所電子状態を 有するナノ構造体表面で, 単一分子レベルの感度および ナノメータスケールの空間分解能を持った分子識別・状 態分析・反応解析法として実用化されるものと期待され る。

\section{謝 辞}

本研究はJSPS 科研費(課題番号「25286014」 $\lceil 25600022 」$ の助成, 抢よびソルト・サイエンス研究財 団平成 26 年度助成（No. 1415）を受けたものです。

\section{文献}

1) K. Kneipp et al. eds. : "Surface Enhanced Raman Scattering”, Top. Appl. Phys. 103 (Springer, 2006).

2) E.C. Le Ru and P.G. Etchegoin : "Principles of Surface-
Enhanced Raman Spectroscopy" (Elsevier, 2009).

3) A. Otto et al. : J. Phys. Condens. Matter. 4, 1143 (2002).

4) M. Futamata et al. : J. Phys. Chem. C 114, 7502 (2010).

5) M. Futamata et al. : J. Phys. Chem. C 115, 5271 (2011).

6) T. Yajima et al. : Phys. Chem. Chem. Phys. 13, 12454 (2011).

7) T. Yajima et al. : J. Raman Spectrosc. 44, 406 (2013).

8) Y. Yu et al. : Chem. Phys. Lett. 560, 49 (2013).

9) S. Handa et al. : Vib. Spectrosc. 72, 128 (2014).

10) P.K. Aravind and H. Metiu : Surf. Sci. 124, 506 (1984).

11) T. Yano et al. : Nat. Commun. 4, 2592 (2013).

12) H. Raether: "Surface Plasmon on Smooth and Rough Surfaces and on Gratings" (Springer-Verlag, 1988).

13) H. Chiba et al. : Vib. Spectrosc. 73, 19 (2014).

14) M. Futamata et al. : Faraday Discussions 178, 203 (2015).

15) T. Okamoto and I. Yamaguchi : Opt. Rev. 6, 211 (1999).

16) K. Ikeda et al. : J. Phys. Chem. C 113, 11816 (2009).

17) K. Kim et al. : J. Phys. Chem. C 115, 13223 (2011).

18) J.F. Li et al : Nature 464, 392 (2010).

19) H. Suzuki et al. : Vib. Spectrosc. 72, 105 (2014).

20) S. Kumar et al. : Chem. Rev. 107, 4797 (2007).

21) P.C. Lee et al. : J. Phys. Chem. 86, 3391 (1982).

22) N.C. Bigall et al. : Phil. Trans. R. Soc. A, 368, 1385 (2010). 